\title{
Five-day planetary waves in the middle atmosphere from Odin satellite data and ground-based instruments in Northern Hemisphere summer 2003, 2004, 2005 and 2007
}

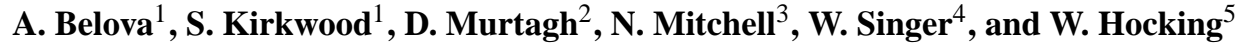 \\ ${ }^{1}$ Swedish Institute of Space Physics, P.O. Box 812, 98128 Kiruna, Sweden \\ ${ }^{2}$ Chalmers University of Technology, Gothenburg, Sweden \\ ${ }^{3}$ University of Bath, Bath, UK \\ ${ }^{4}$ Leibniz Institute for Atmospheric Physics, Kühlungsborn, Germany \\ ${ }^{5}$ University of Western Ontario, London, Ont., N6A 3K7, Canada
}

Received: 13 December 2007 - Revised: 8 July 2008 - Accepted: 10 October 2008 - Published: 17 November 2008

\begin{abstract}
A number of studies have shown that 5-day planetary waves modulate noctilucent clouds and the closely related Polar Mesosphere Summer Echoes (PMSE) at the summer mesopause. Summer stratospheric winds should inhibit wave propagation through the stratosphere and, although some numerical models (Geisler and Dickinson, 1976) do show a possibility for upward wave propagation, it has also been suggested that the upward propagation may in practice be confined to the winter hemisphere with horizontal propagation of the wave from the winter to the summer hemisphere at mesosphere heights causing the effects observed at the summer mesopause. It has further been proposed (Garcia et al., 2005) that 5-day planetary waves observed in the summer mesosphere could be excited in-situ by baroclinic instability in the upper mesosphere. In this study, we first extract and analyze 5-day planetary wave characteristics on a global scale in the middle atmosphere (up to $54 \mathrm{~km}$ in temperature, and up to $68 \mathrm{~km}$ in ozone concentration) using measurements by the Odin satellite for selected days during northern hemisphere summer from 2003, 2004, 2005 and 2007. Second, we show that 5-day temperature fluctuations consistent with westward-traveling 5-day waves are present at the summer mesopause, using local ground-based meteor-radar observations. Finally we examine whether any of three possible sources of the detected temperature fluctuations at the summer mesopause can be excluded: upward propagation from the stratosphere in the summer-hemisphere, horizontal propagation from the winter-hemisphere or in-situ excitation as a result of the baroclinic instability. We find that in one case, far from solstice, the baroclinic instability is unlikely to be involved. In one further case, close to solstice, upward prop-
\end{abstract}

Correspondence to: A. Belova

(allab@irf.se) agation in the same hemisphere seems to be ruled out. In all other cases, all or any of the three proposed mechanisms are consistent with the observations.

Keywords. Meteorology and atmospheric dynamics (Middle atmosphere dynamics; Waves and tides)

\section{Introduction}

Large scale Rossby waves, planetary waves with horizontal wavelengths of thousands of kilometers and with periods up to several days, form a well-known class of atmospheric waves. A prominent mode of this group in the stratosphere and mesosphere is the 5-day wave which is the gravest symmetric wavenumber 1 westward traveling Rossby mode (Andrews et al., 1987). Early theoretical predictions of the 5-day planetary wave characteristics, for example, by Geisler and Dickinson (1976) and Salby (1981a, b), have later been confirmed by both ground based and satellite observations (Hirota and Hirooka, 1984; Hirooka, 2000; Lawrence and Jarvis, 2003; Garcia et al., 2005; Riggin et al., 2006). The temperature disturbance is associated with the amplitude peaks at midlatitudes and is symmetric about the equator at all heights during equinox. During solstice conditions, the wave is not symmetric about the equator in the mesosphere and wave amplitudes may be greater in the summer mesosphere (Geisler and Dickinson, 1976; Salby, 1981b). The period of 5-day planetary waves varies with season (Salby, 1981a, b). Results based on the space observations from Nimbus-6 (Prata, 1989) indicate a period closer to 6 days in spring and autumn (equinox conditions) and about 5.2 days in summer and winter (solstice conditions).

Published by Copernicus Publications on behalf of the European Geosciences Union. 
In several papers a relationship has been found between 5-day planetary waves and other natural events in the summer polar mesosphere. For example, using local groundbased radar observations and UKMO assimilated global data, it was found that variations in Polar Mesosphere Summer Echoes (PMSE) at heights $80-90 \mathrm{~km}$ are closely anti correlated with temperature variations associated with 5-day planetary waves in the stratosphere at the $1 \mathrm{mb}$ level (Kirkwood and Réchou, 1998; Kirkwood et al., 2002). In the experimental studies by Kirkwood et al. (2002) and Kirkwood and Stebel (2003) a correlation was demonstrated between the probability of observing noctilucent clouds (NLC, which include the clouds known as PMC, but are observed by groundbased instruments, at $80-85 \mathrm{~km}$ heights) and the combined effects of stationary, 16-day and 5-day planetary waves at the NLC location. In an experimental study based on data from the Student Nitric Oxide Explore Satellite (SNOE) by Merkel et al. (2003) it was found that variations in the brightness of Polar Mesospheric Clouds (PMC) had a 5-day period which corresponded to the 5-day wave observed in the polar summer mesosphere at high latitudes. This result has been confirmed in another paper by Merkel et al. (2008) who also compared the brightness of PMCs seen by SNOE with mesospheric temperatures by the SABER instrument aboard the TIMED satellite, for the summer seasons in both hemispheres during 2002-2003. Their results show the presence of planetary wave activity in both PMCs and mesospheric temperatures that are strongly correlated to each other and one of the dominant waves is a 5-day wave with wavenumber 1 .

In another experimental study, von Savigny et al. (2007), considered the NH summer of 2005, and reported a good general agreement in the quasi 5-day wave activity of NLC occurrence rates (using SCIAMACHY/Envisat limb scattering measurements) and the mesosphere temperature field (from temperature profiles measured with MLS/Aura), indicating that planetary wave signatures in the temperature field are the main driver of corresponding signatures in NLCs.

The observations of 5-day wave effects at the summer mesopause are somewhat surprising since the upward propagation of 5-day planetary waves should be effectively hindered by the prevailing westward winds in the summer stratosphere and mesosphere. Although some numerical models (Geisler and Dickinson, 1976) do show a possibility for upward wave propagation, it has also been suggested that the upward propagation may in practice be confined to the winter hemisphere with horizontal propagation of the wave from the winter to the summer hemisphere at mesosphere heights causing the effects observed at the summer mesopause.

Another possible source for planetary waves in the summer polar mesosphere is the baroclinic instability of the easterly jet in summer time. Plumb (1983) discussed theoretically the possible occurrence of such baroclinic instability. He pointed out that, around the solstices, the stratospheric easterlies in the summer hemisphere intensify because of heating in the high-latitudes regions. Almost at the same time, a strong westerly shear develops in the upper mesosphere driven by internal gravity wave stress (Holton, 1982; Matsuno, 1982). Eventually this shear may become so strong that the jet becomes baroclinically unstable, a process that could lead explain the appearance of the two-day planetary wave. Garcia et al. (2005), who extracted planetary-scale waves from temperature data measured by the SABER instrument, have found that not only the "2-day wave" attains large amplitudes during the solstice in the summer mesosphere, but a spectrum of waves, including the 5-day wave, that cluster along a line of constant westward phase velocity. The observed structure of these waves, and the fact that they were found to be present with high amplitude only close to the solstices, was found to be consistent with excitation of a spectrum of atmospheric normal modes by baroclinic instability of the easterly summer jet in the mesosphere. In another experimental study based on the SABER measurements, (Riggin et al., 2006) found that the 5-day wave propagated upwards in the winter hemisphere but was then amplified at the summer high-latitude mesosphere by baroclinic instability.

In this paper we use both global satellite observations and local ground-based radar observations to investigate the 5day wave behavior. Space and time filtering of satellite and ground-based data are used to distinguish 5-day planetary waves from other atmospheric phenomena and to investigate their propagation characteristics between the stratosphere and the mesosphere.

\section{Data sources and technique of data analysis}

The Odin satellite (Murtagh et al., 2002) was placed into a $600 \mathrm{~km}$ sun-synchronous, terminator orbit on 20 February 2001. One of the Odin instruments is an advanced sub$\mathrm{mm}$ radiometer (SMR) which is used for both astronomy and aeronomy missions. In this work we use retrieved ozone and temperature profiles (level-2 version 2.0) produced at the Chalmers University of Technology (Gothenburg) from measurements of the Odin Sub-Millimetre Radiometer (SMR) at $544.6 \mathrm{GHz}$ (Frisk et al., 2003; Olberg et al., 2003; Urban et al., 2005).

The principal data source for this study is the set of retrieved profiles (from Odin) of the temperature between 24$54 \mathrm{~km}$ and ozone mixing ratio between $18-68 \mathrm{~km}$ (with vertical resolution about $2 \mathrm{~km}$ ). In this work we use Odin temperature and ozone profiles with measurement response $>75 \%$ (i.e. the retrieved value is less than $25 \%$ dependent on the initial profile used in the retrieval). The estimated uncertainty in the Odin profiles for temperature is about $0.5-1 \%$ at $24-$ $40 \mathrm{~km}$ and about $1-3 \%$ at $40-56 \mathrm{~km}$, and for ozone is about $5-10 \%$ at $24-50 \mathrm{~km}$ and about $10-30 \%$ at $50-68 \mathrm{~km}$. The available periods of sufficiently continuous measurements (each third day) are three NH summer periods 15 July-13 
August 2003, 14 June-11 August 2004, 27 July-17 September 2005. There is also one time period available with continuous measurements each second day, 22 May-17 June 2007.

Note that the ozone retrievals are reliable over a much larger height range than the temperature retrievals. The retrieved fields of temperature and ozone mixing ratio are available between $82^{\circ} \mathrm{N}$ and $82^{\circ} \mathrm{S}$ on a grid of about $7^{\circ}$ in latitude and $30^{\circ}$ in longitude at mid-latitudes and $15^{\circ}-20^{\circ}$ at high latitudes. These data have been linearly interpolated to a $2.5^{\circ} \times 3.75^{\circ}$ latitude-longitude grid for the analysis described in this paper. Missing orbits and short data gaps in time have also been linearly interpolated. The fraction of missing orbits in our case is about $5 \%$ of all available data.

Complete coverage of all longitudes is provided by Odin in $12 \mathrm{~h}$ (using both ascending and descending nodes). In order to extract the signatures of 5-day planetary waves, we first extract the wave-component with spatial wavenumber 1 from each $12 \mathrm{~h}$ period of global coverage. This is done by applying a spatial Fourier transform to the values of temperature or ozone concentration around each latitude circle, at each height. The lowest harmonic component represents wavenumber one. In order to find the "5-day" temporal component, we then apply a time-domain band-pass filter (4-6 day band-pass) to the time series of the complex amplitude (equivalent to the amplitude and spatial phase) of this lowest harmonic spatial component. By using a bi-directional filter we avoid introducing artificial phase shifts and, by using a filter with complex coefficients, we are able to extract only westward travelling waves. Odin's observing schedule is usually such that it makes atmospheric observations in two consecutive 12-h periods, then there is a gap of 24 or $48 \mathrm{~h}$ (depending on measurement schedule), followed by two more 12-h observation periods. This gap has to be filled by interpolation of the wavenumber one amplitude and phase. The 5-day waves should have slowly varying amplitude and a steady phase progression around the globe, taking 5-days for a complete circuit. Thus the interpolation can accurately represent these waves provided there are no strong disturbing signals from waves with shorter periods than the data gap. Fortunately, according to published analyses of observations from other satellites, we can expect 3-day and longer periods to dominate at wave number 1 (Hirota and Hirooka, 1984; Hirooka and Hirota, 1985; Venne, 1985). The final result of this procedure is a time series, with $12 \mathrm{~h}$ time resolution, of the amplitude and spatial phase of the westward travelling, spatial wavenumber one, 4-6 day wave, separately for each latitude and height in the original grid. This can be used to recalculate the perturbation due to the wave as a time series for any latitude, longitude and height. We call the temperature (or ozone mixing ratio) variation due to the 5-day wave, calculated for a particular location, a "5-day perturbation".

Validation of the Odin ozone data has been reported by Kopp et al. (2007), who made an intercomparison of Odin-SMR ozone profiles with ground-based ozone observations. The results showed that the Odin measurements at
$544.9 \mathrm{GHz}$ yielded a systematic bias of $20-30 \%$ lower ozone mixing ratios in the middle stratosphere than the groundbased measurements. However, in our work, only perturbations in ozone are evaluated and any systematic bias in the absolute values of ozone mixing ratio should not affect our results.

To check the Odin temperature retrievals (from the $544.9 \mathrm{GHz}$ channel) we have compared with temperature data (version 2.2, level 2) obtained by the Microwave Limb Sounder (MLS) experiment during the Aura mission (Schwartz et al., 2008) for the period 27 July-17 September 2005. The results show 5-15\% lower values of the zonal mean temperature from the Odin data compared to MLS. A comparison (not shown) between the 5-day temperature perturbations extracted from the Odin and Aura data demonstrates that the perturbation amplitudes in the winter stratosphere, where planetary waves are strong, have almost the same magnitude (1-4 K from Odin, $1-5 \mathrm{~K}$ from Aura) and the perturbation phases and amplitude changes are very similar between the data sets. Thus, it seems that the Odin data are sufficiently reliable to estimate the properties of 5-day planetary waves, at least for locations and time intervals with reasonably large wave amplitude.

For additional information on planetary wave properties, we use ground-based measurements obtained with meteor radars located in northern Sweden at Esrange $\left(67^{\circ} 56^{\prime} \mathrm{N}\right.$, $\left.21^{\circ} 04^{\prime} \mathrm{E}\right)$, in northern Norway, at Andenes $\left(69^{\circ} 17^{\prime} \mathrm{N}\right.$, $\left.16^{\circ} 00^{\prime} \mathrm{E}\right)$, in northern Canada, at Resolute Bay, $\left(74^{\circ} 30^{\prime} \mathrm{N}\right.$, $\left.95^{\circ} 00^{\prime} \mathrm{W}\right)$ and at Yellowknife, $\left(62^{\circ} 30^{\prime} \mathrm{N}, 114^{\circ} 32^{\prime} \mathrm{W}\right)$. The decay time of meteor trails is used to provide estimates of temperature between $85-90 \mathrm{~km}$ height. The technique of deriving temperature from meteor echoes can be found in Hocking et al. (2004) and references there-in. Ground-based measurements in this case are the time series of average temperature for each day. Temperature data for 2003 and 2007 were obtained from the meteor radar at Esrange; for 2004 - from meteor radars at Andenes, Resolute Bay and Yellowknife; for 2005 - from meteor radars at Esrange, Resolute Bay and Yellowknife.

The time series of temperature data from the meteor radars have been filtered, using the same bandpass as for the Odin data, to extract wave components with periods of 4-6 days, to match the 5-day waves found from the satellite data. Note that we cannot distinguish between perturbations due to wavenumber 1 and higher-order waves, nor between westward and eastward traveling disturbances, nor contributions from non-periodic changes, in these temperature data.

To test the significance of the extracted 5-day waves, a random permutation technique has been used. For the Odin data, 10000 random permutations have been applied to the complex amplitudes of the wave number one components in ozone and temperature. Then, the filtering procedure has been performed to extract a 5-day wave from the each obtained random wave number one. The obtained 10000 random 5-day waves are statistically independent with respect 

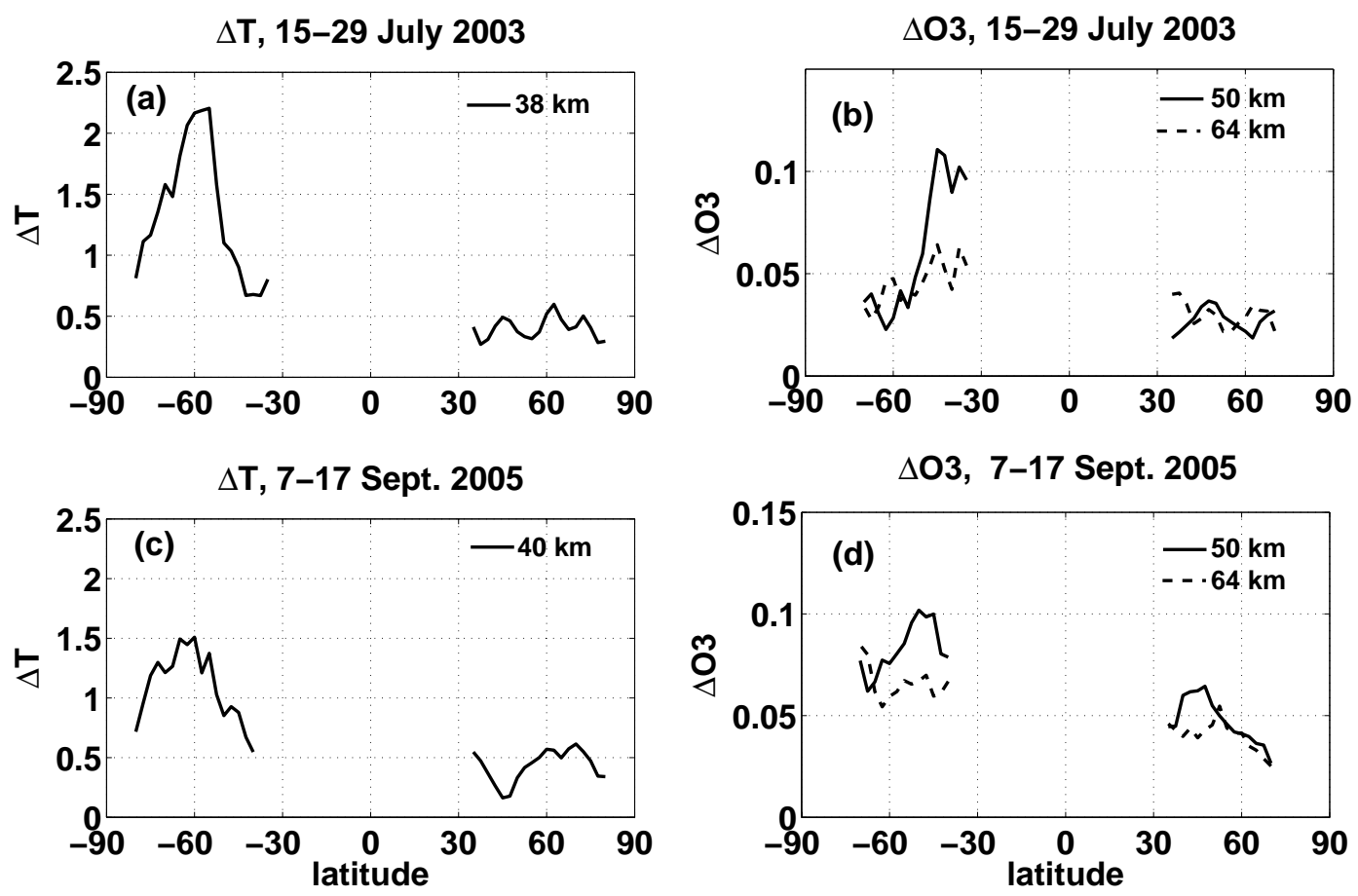

Fig. 1. Mean amplitude of the 5-day planetary wave as a function of latitude from measurements by Odin over the period 15-29 July, days 196-210, 2003 (a, b) and 7-17 September, days 250-260, 2005 (c, d). Left hand panels are for the wave in temperature (K) at $38 \mathrm{~km}$ (a) and $40 \mathrm{~km}(\mathrm{c})$, right hand panels are for the wave in ozone (ppmv) at $50 \mathrm{~km}$ (solid line) and $64 \mathrm{~km}$ (dashed line).

to the original 5-day wave calculated from non-permutated wave number one. Finally, a comparison between random 5day waves and the original 5-day wave has been made on the basis of the maximal wave amplitude (i.e. if the amplitude of the original wave is higher than $80 \%$ of the wave amplitudes resulting from random permutation of the data, we say it is of $80 \%$ significance). The significance of the 5-day temperature waves from the meteor radar data has been tested in the same way by applying the same random permutation technique but to the daily temperature estimates, and then, amplitude comparison between the original and random 5-day waves.

An additional test on the significance of the calculated 5day waves in the Odin data has been performed using the well-known physical property of this wave, that it should show phase coherence between different latitudes at middle latitudes. Latitude bands between $40^{\circ}-60^{\circ} \mathrm{N}$ and $40^{\circ}-60^{\circ} \mathrm{S}$ have been considered for all heights and for each period to select those time intervals when the 5-day wave shows a phasecoherent pattern for the whole latitude band. Only one or two short time intervals have been found in each available measurement period when this criterion is satisfied. Note that for some intervals there is a substantial phase shift between the wave structures observed at the equivalent latitude bands in opposite hemispheres. This behaviour is not a contra-indication of 5-day waves. For example, Prata (1989) demonstrated that the phase of the 5-day temperature wave, derived using a barotropic normal mode model, could change up to $180^{\circ}$ between $60^{\circ}-70^{\circ} \mathrm{S}$ and $60^{\circ}-70^{\circ} \mathrm{N}$ (for solstice conditions in the case of no background winds in the middle atmosphere).

Finally, we use winds from the meteor-radar at Esrange to give a measure of the 2-day wave amplitude at mesopause heights. As discussed in the introduction, this wave is considered to be produced by baroclinic instability, so that changes in its amplitude should give a good indication of whether the latter source is generating strong waves, or not. Temperature estimates from the meteor radars can be made only with 24-h time resolution so they are not very suitable to look for 2-day waves. Winds are routinely measured with 1-h time resolution, and the 2-day wave is readily detected in the winds (e.g. Pancheva et al., 2004). For the present study we use meridional wind and apply a filter with bandpass of 36-54 h.

Note that the periods under study here include different seasonal conditions: 22 May-17 June, 2007 - represents early summer and pre-solstice condition; 14 June-11 August, 2004 - covers the solstice; 15 July-13 August, 2003 - corresponds to the period between the solstice and equinox; 27 July-17 September 2005 - contains a part of the transition period and pre-equinox conditions. 
(a)

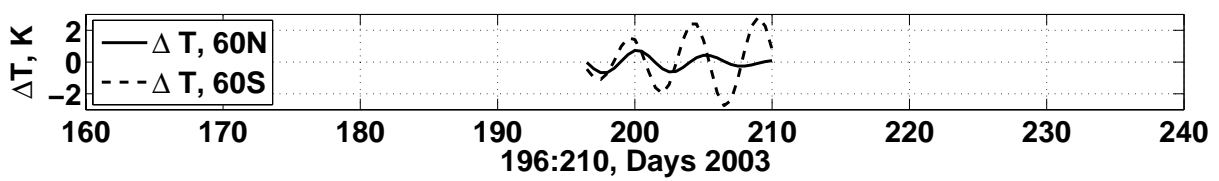

(b)

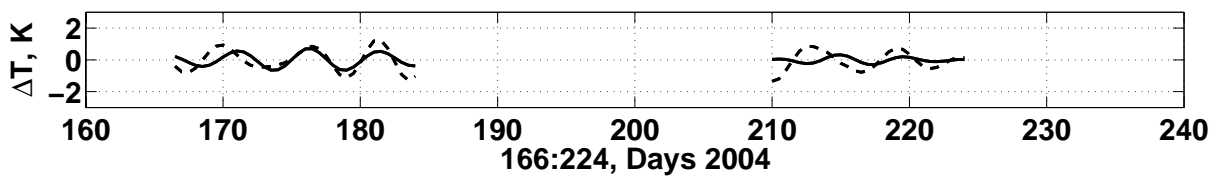

(c)

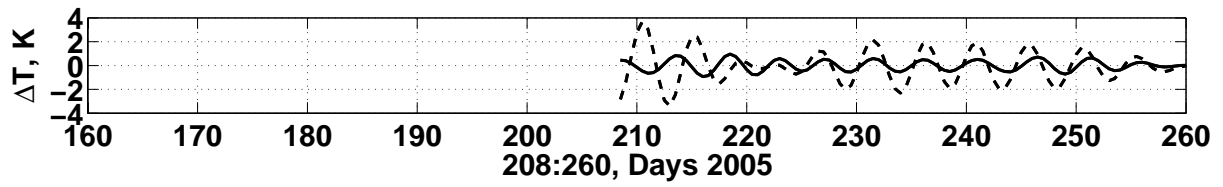

(d)

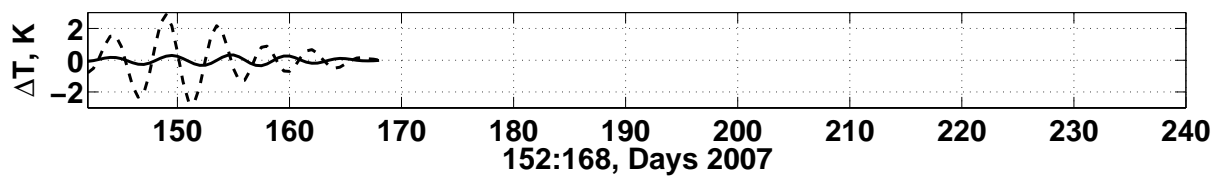

Fig. 2. 5-day perturbations from Odin temperature retrievals. Solid lines are for $60^{\circ} \mathrm{N}$, dashed lines are for $60^{\circ} \mathrm{S}$. (a) for period $15-27 \mathrm{July}$ 2003; altitude $=38 \mathrm{~km}$, longitude $=21^{\circ} \mathrm{E}$. (b) for period 14 June- 11 August 2004, altitude $=40 \mathrm{~km}$, longitude $=16^{\circ} \mathrm{E}$. (c) for period $27 \mathrm{July}-17$ September 2005 , altitude $=42 \mathrm{~km}$, longitude $=21^{\circ} \mathrm{E}$. (d) for period 22 May-17 June 2007, altitude $=46 \mathrm{~km}$, longitude $=21^{\circ} \mathrm{E}$.

\section{Results}

\subsection{Planetary wave characteristics from the Odin data}

\subsubsection{Mean amplitudes of the 5-day wave in temperature and ozone}

First, we consider the 5-day planetary waves (with significance more than $80 \%$ ) in the stratosphere obtained from the temperature and ozone data using Odin. Figure 1 demonstrates the mean amplitude of the 5-day wave for two short time intervals when coherent wave-phase has been observed between $40^{\circ}-60^{\circ} \mathrm{N}$ and between $40^{\circ}-60^{\circ} \mathrm{S}$. The wave amplitude is shown as a function of latitude during the Northern Hemisphere (NH) summer periods of 2003 (15-29 July, a, b) and 2005 (7-17 September, c, d). Left hand panels are for the wave amplitude in temperature $(\mathrm{K})$ at $38-40 \mathrm{~km}$ and right hand panels are for the wave amplitude in ozone (ppmv) at 50 and $64 \mathrm{~km}$. The common feature of the curves in Fig. 1 is that the 5-day wave is observed in both hemispheres but with highest amplitude (more than $2 \mathrm{~K}$ in temperature and more than $0.1 \mathrm{ppmv}$ in ozone) in the winter hemisphere (Southern Hemisphere, $\mathrm{SH}$ ) at $50^{\circ}-60^{\circ} \mathrm{S}$. In the summer hemisphere (NH) the wave amplitude in temperature is equal to $0.2-0.6 \mathrm{~K}$ and in ozone equal to $0.025-0.06$ ppmv. These wave amplitudes have the same range as Prata $(1989,1990)$ has obtained for the 5-day planetary wave using temperature and ozone from the SBUV-instrument on the Nimbus- 6 and Nimbus-7 satellite data.

Note that the difference between wave amplitudes in opposite hemispheres in Fig. 1c, d (7-17 September 2005) is slightly less than in Fig. 1a, b (15-29 July 2003), likely be- cause the first case is closer to the equinox when the amplitudes should be approximately equal and symmetric relative to the equator.

3.1.2 Characteristics of the 5-day perturbations in ozone and temperature at $60^{\circ} \mathrm{N}$ and $60^{\circ} \mathrm{S}$

One of the typical characteristics expected for 5-day planetary waves is a global pattern with a (usually) symmetric phase structure relative to the equator. Study of the wave phase has been performed (see the second last paragraph in Sect. 2) for the latitude bands between $40^{\circ}-60^{\circ} \mathrm{N}$ and $40^{\circ}-$ $60^{\circ} \mathrm{S}$ and the results show that, even when the wave pattern is coherent over the whole band in each hemisphere, sometimes there is a phase difference between the latitude bands in the opposite hemispheres. To see whether our observations usually show asymmetry about the equator we compare the phases of the 5-day perturbations in the highlatitude regions at $60^{\circ} \mathrm{N}$ and $60^{\circ} \mathrm{S}$ in Fig. 2, which represents the 5-day perturbations of temperature at $38-46 \mathrm{~km}$ for the NH summers 2003, 2004, 2005 and 2007. The curves for the different periods are shown at slightly different altitudes, chosen to correspond to the highest significance $(>75 \%)$ of the 5-day perturbations. Figure $2 \mathrm{a}, \mathrm{c}, \mathrm{d}$ illustrates the perturbations at longitude $=21^{\circ} \mathrm{E}$, over Esrange and Fig. $2 \mathrm{~b}$ at longitude $=16^{\circ} \mathrm{E}$, over Andenes. This is for comparison later with meteor-radar data and is of no importance for the comparison between the hemispheres. The 5-day perturbations tend to have the same phase in both hemispheres most of the time - days 175-184, 2004 (Fig. 2b), days 225-260, 2005 (Fig. 2c) and days 142-150, 2007 (Fig. 2d). For the other 
(a)

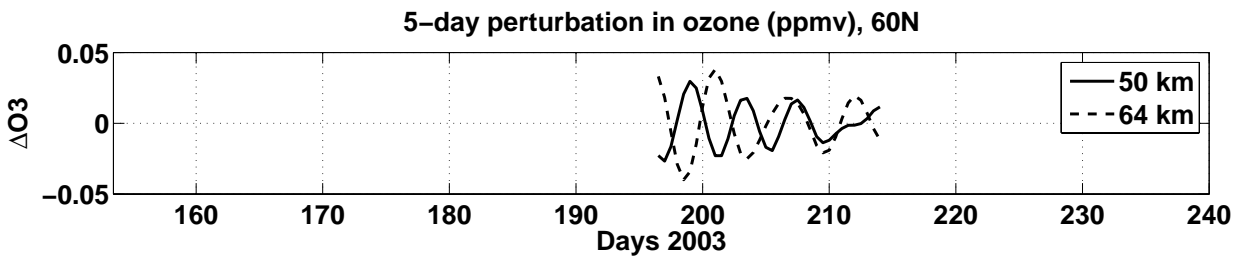

(b)

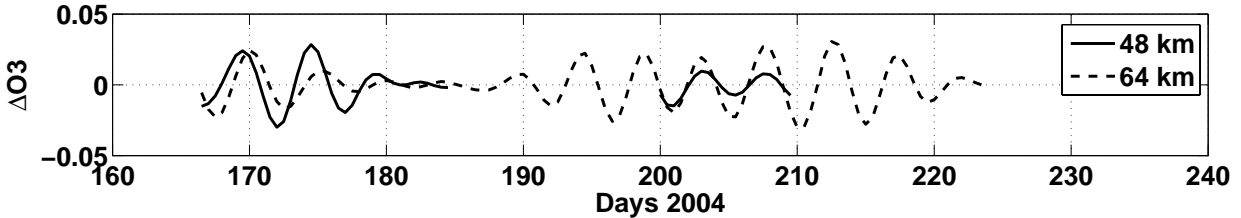

(c)

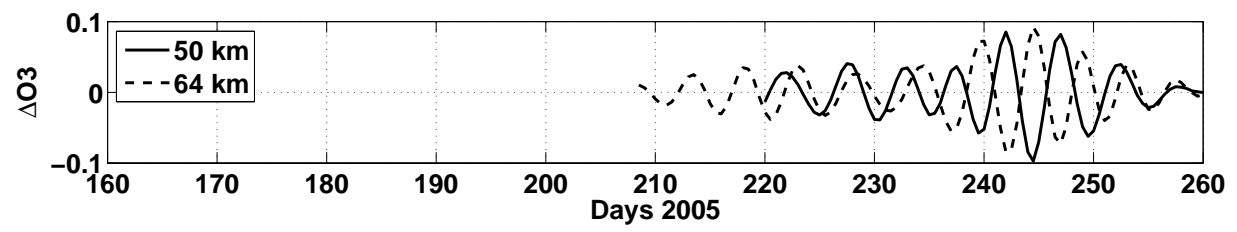

(d)

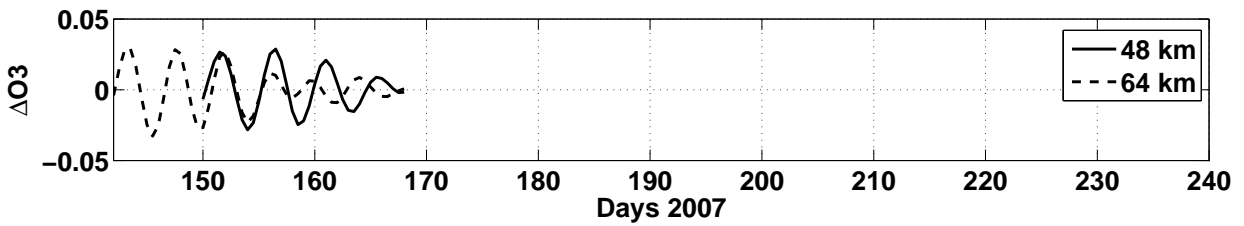

Fig. 3. 5-day ozone perturbations from Odin at $60^{\circ} \mathrm{N}$ for the $\mathrm{NH}$ summers of 2003, 2004, 2005 and 2007.

Table 1. Amplitudes of 5-day temperature perturbations at $38-$ $46 \mathrm{~km}$ height.

\begin{tabular}{lcc}
\hline & $\begin{array}{c}\text { Summer } \\
\text { hemisphere, } \\
60^{\circ} \mathrm{N}\end{array}$ & $\begin{array}{c}\text { Winter } \\
\text { hemisphere, } \\
60^{\circ} \mathrm{S}\end{array}$ \\
\hline Fig. 2a (2003), 38 km & $0.2-0.6 \mathrm{~K}$ & $0.5-2.7 \mathrm{~K}$ \\
Fig. 2b (2004), 40 km & $0.1-0.6 \mathrm{~K}$ & $0.5-1.5 \mathrm{~K}$ \\
Fig. 2c (2005), 40 km & $0.1-0.9 \mathrm{~K}$ & $0.5-3.9 \mathrm{~K}$ \\
Fig. 2d (2007), 46 km & $0.1-0.5 \mathrm{~K}$ & $0.5-2.9 \mathrm{~K}$ \\
\hline
\end{tabular}

time intervals there is a phase shift between the perturbations in the opposite hemispheres at $60^{\circ} \mathrm{N}$ and $60^{\circ} \mathrm{S}$, at most 1.5 days, corresponding to $\sim 108^{\circ}$ for the 5-day wave.

Also the 5-day perturbation in ozone has been examined. These perturbations are plotted in Figs. 5-8 as lines (b) and (c) and will be discussed in detail later in Sect. 3.3. For the moment we note only that the global pattern with approximately symmetric phase structure about to the equator, including high latitudes $\left(60^{\circ} \mathrm{N}\right.$ and $\left.60^{\circ} \mathrm{S}\right)$, is found in ozone perturbations for days 196-214, 2003 (Fig. 5, curve b) and days 210-224, 2004 (Fig. 6, curve b) at 64-68 km.

A further feature of the waves in temperature and ozone, which is apparent in Figs. 2 and 5-8 is that the amplitudes of 5-day perturbations are highest in the SH (dashed lines in
Fig. 2 only) for all periods. Tables 1 and 2 summarize the amplitudes of the 5-day perturbations in temperature and ozone as plotted in the figures. Amplitudes in temperature are about 2-5 times more in the $\mathrm{SH}$ (winter) than in the $\mathrm{NH}$ (summer). The 5-day perturbation amplitudes in ozone are also generally greater in the winter hemisphere $\left(\right.$ at $60^{\circ} \mathrm{S}$ ) than in summer one $\left(\right.$ at $\left.60^{\circ} \mathrm{N}\right)$. But there is one case when a large amplitude $(\sim 0.1 \mathrm{ppmv})$ is observed at $60^{\circ} \mathrm{N}$. This occurs just before the equinox in September 2005 (days 240-250, upper panel in Fig. 7, curves c, b) at 50 and $64 \mathrm{~km}$, and the amplitude values have the same magnitude range as the ozone perturbations in the opposite hemisphere at $60^{\circ} \mathrm{S}$ (days 240 250, lower panel in Fig. 7, curves c, b). This is likely due to the near-equinox conditions, when the 5-day perturbations should have approximately equal amplitudes in both hemispheres. In temperature perturbations for this interval the amplitude is still greater at $60^{\circ} \mathrm{S}$ than at $60^{\circ} \mathrm{N}$.

To summarize, the 5-day perturbations in temperature and ozone show larger amplitudes in the SH (winter) than in the NH (summer), as expected because of more favorable conditions for wave propagation in the winter hemisphere than in the summer one, due to the eastward and westward zonal winds in the stratosphere in winter and summer, respectively. The global pattern with approximately symmetric phase structure between the hemispheres, including high latitudes $\left(60^{\circ} \mathrm{N}\right.$ and $\left.60^{\circ} \mathrm{S}\right)$, is found most of the time in temperature perturbations at $\sim 40 \mathrm{~km}$ height and part of the time in ozone perturbations at $64-68 \mathrm{~km}$ height. The higher 
Table 2. Amplitudes of the 5-day ozone perturbations (ppmv) at $48-50 \mathrm{~km}$ and $64-68 \mathrm{~km}$, at $60^{\circ} \mathrm{N}$ and $60^{\circ} \mathrm{S}$.

\begin{tabular}{lcccc}
\hline & $60^{\circ} \mathrm{N}, 48-50 \mathrm{~km}$ & $60^{\circ} \mathrm{N}, 64 \mathrm{~km}$ & $60^{\circ} \mathrm{S}, 48-50 \mathrm{~km}$ & $60^{\circ} \mathrm{S}, 64-68 \mathrm{~km}$ \\
\hline Fig. 5c, b (2003) & $0.007-0.03$ & $0.01-0.04$ & $0.05-0.13$ & $0.05-0.13$ \\
Fig. 6c, b (2004) & $0.02-0.03$ & $0.01-0.035$ & $0.025-0.1$ & $0.025-0.1$ \\
Fig. 7c, b (2005) & $0.025-0.1$ & $0.025-0.07$ & $0.05-0.125$ & $0.05-0.1$ \\
Fig. 8c, b (2007) & $0.007-0.03$ & $0.01-0.03$ & $0.015-0.03$ & $0.05-0.1$ \\
\hline
\end{tabular}

amplitudes in the winter hemisphere, the general phasesymmetry but occasional lack of phase-symmetry about the equator coincides with conclusions reached in several previous works. For example, Hirota and Hirooka (1984) showed that spatially irregular patterns of the 5-day wave amplitude appear in the winter season of both hemispheres with maximum amplitude near $70^{\circ}$ latitude. The latter results were obtained using TIROS-N and NOAA-A satellite temperature measurements and demonstrated that 5-day wave amplitudes in the upper stratosphere in the winter hemisphere are about 5 times more those in the summer hemispheres. Similar results have been found by Prata $(1989,1990)$ who also found a small but noticeable asymmetry in the amplitude and phase structure of the 5-day wave at $42 \mathrm{~km}$ during the solstices using observations from the Nimbus- 6 and Nimbus-7 satellites (up to $90^{\circ} / 120^{\circ}$ phase difference in temperature/ozone between opposite hemispheres). Also, the amplitude asymmetry in the present data coincides with theoretical considerations by Miyoshi (1999) who predicted that the 5-day wave amplitude in the stratosphere in the winter hemisphere is larger than in the summer hemisphere, based on a general circulation model. Garcia et al. (2005) have demonstrated, based on measurements in made in 2002-2004 by the SABER instrument, that the global (symmetric) mode of the 5-day wave was detected clearly only in near-equinox data, and the wave was not distinctly identified as a global mode during the northern or southern winter solstice.

\subsubsection{Phase change in the 5-day ozone perturbations with height at $60^{\circ} \mathrm{N}$}

As the ozone data from Odin are available for a large height range (up to $68 \mathrm{~km}$ ), it is possible to study the phase change in the ozone perturbation with height in the summer hemisphere. Figure 3 shows the ozone perturbations at $48-50 \mathrm{~km}$ and $64 \mathrm{~km}$ at $60^{\circ} \mathrm{N}$ for the $\mathrm{NH}$ summer of 2003 (a), 2004 (b), 2005 (c) and 2007 (d). In Fig. 3 one can see a phase shift between the ozone perturbations by up to $180^{\circ}$ for some time intervals. Several previous studies show similar phase shifts. The experimental study by Rosenlof and Thomas (1990) has demonstrated a nearly $90^{\circ}$ phase shift between 50 and $64 \mathrm{~km}$ (and $180^{\circ}$ phase shift between 50 and $95 \mathrm{~km}$ ) in a 5-day ozone wave in the summer hemisphere (results based on the Solar Mesosphere Explorer (SME) ozone data).
In the model simulation by Salby (1981b), it was found that the phase shift between 50 and $70 \mathrm{~km}$ could be between $45^{\circ}-$ $135^{\circ}$, depending on wind conditions. Another model result by Geisler and Dickinson (1976) has shown a phase shift up to $180^{\circ}$ between 42 and $70 \mathrm{~km}$ at $60^{\circ}$ latitude for the case of strong solstice zonal wind. Thus, our results are not contrary to the previous studies.

3.2 Planetary wave characteristics at the summer mesopause obtained by ground-based meteor radars

Temperatures close to the mesopause $(85-90 \mathrm{~km})$, as measured by meteor radars, over northern Scandinavia (Andenes and Esrange) and Canada (Yellowknife and Resolute Bay) are used here to look for evidence of the 5-day wave at mesopause heights. Statistical significances of the 5-day temperature perturbations extracted from the meteor radar temperatures are generally high, between $74 \%$ and $97 \%$.

For the NH summers 2004 and 2005, the meteor-radar temperature data sets are available for several locations and the calculated 5-day perturbations from these data are presented in Fig. 4. The upper panel of Fig. 4 shows the 5-day temperature variations over Yellowknife, Resolute Bay and Andenes for 2004; the lower panel illustrates the 5-day oscillations over Yellowknife, Resolute Bay and Esrange for 2005. For the summers of 2003 and 2007, only temperature data over Esrange are considered and the extracted 5-day perturbations for these periods are shown as line (a) in Figs. 5, 7 and 8 (these figures will be discussed further in Sect. 3.3).

These figures show that, in general, the waves appear in bursts in the summer mesopause region with amplitudes reaching $\sim 2.5-5 \mathrm{~K}$. This is in agreement with experimental results by Merkel et al. (2008) who found wave amplitudes of $2-3.5 \mathrm{~K}$ around the summer mesopause in 2002-2003 using results from the SABER instrument on the TIMED satellite. The maximum wave amplitude, $\sim 15 \mathrm{~K}$, is observed over Yellowknife for the summers of 2004 and 2005 (dashed lines in Fig. 4). This high wave amplitude supports the simulation results by Geisler and Dickinson (1976) who suggested that the 5-day wave amplitude in the summer mesosphere could reach as much as $10 \mathrm{~K}$.

In Fig. 4 (lower panel) one can see a 1.5-2 day time delay during days 222-233 and about 2.5 day phase shift for days 234-260 between waves observed over northern 

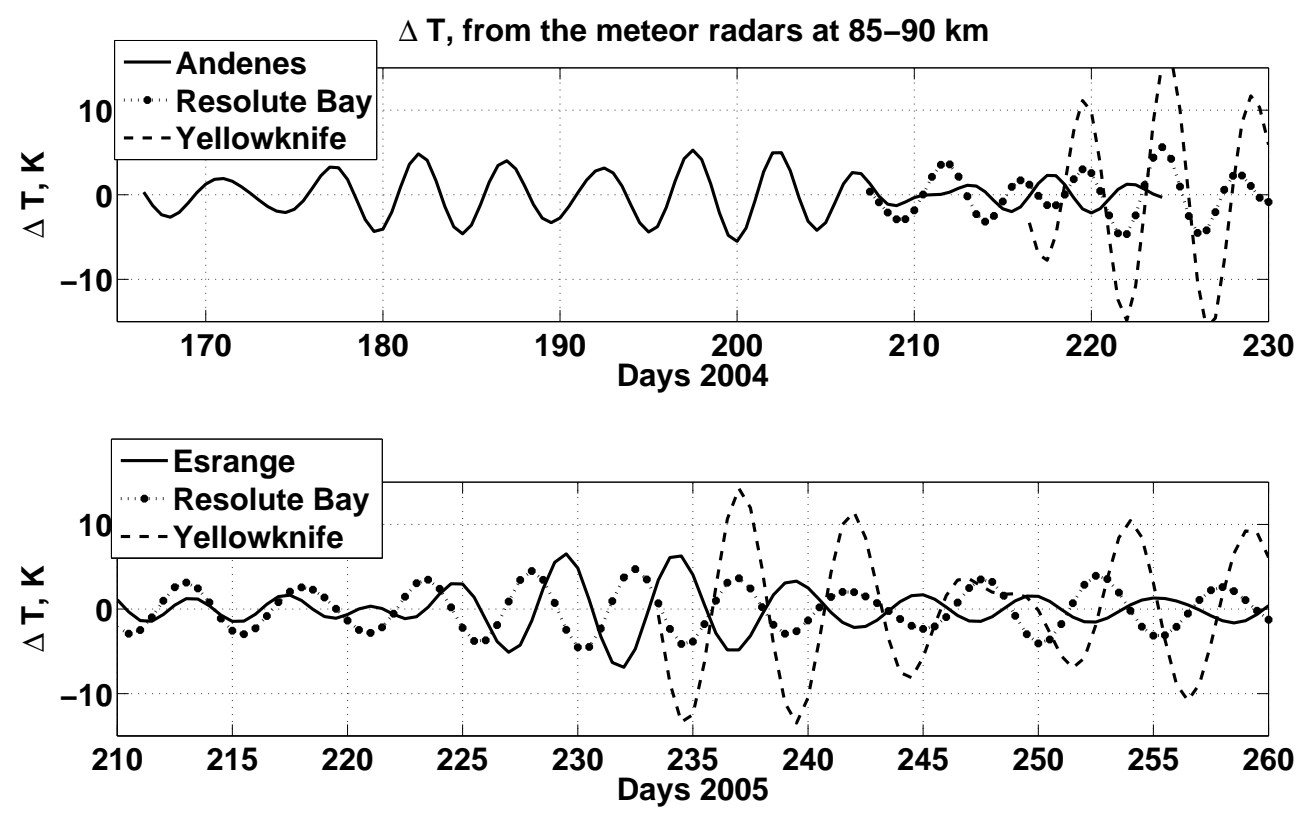

Fig. 4. 5-day wave perturbations obtained from ground-based radar measurements of temperature by meteor radars: Upper panel: for 14 June-11 August 2004. Solid line is from temperature data over Andenes $\left(69^{\circ} 17^{\prime} \mathrm{N}, 16^{\circ} 00^{\prime} \mathrm{E}\right)$, at $90 \mathrm{~km}$; dashed line is from temperature data over Yellowknife, $\left(62^{\circ} 30^{\prime} \mathrm{N}, 114^{\circ} 32^{\prime} \mathrm{W}\right)$ at $88 \mathrm{~km}$; dotted line is from temperature data over Resolute Bay $\left(74^{\circ} 30^{\prime} \mathrm{N}, 95^{\circ} 00^{\prime} \mathrm{W}\right)$ at $87 \mathrm{~km}$. Lower panel: for 27 July-17 September 2005. Solid line is from temperature data over Esrange $\left(67^{\circ} 56^{\prime} \mathrm{N}, 21^{\circ} 04^{\prime} \mathrm{E}\right)$, at $85 \mathrm{~km}$; dashed and dotted lines are from Yellowknife and Resolute Bay, respectively.

Scandinavia (solid line) and over Canada (dotted line). The phase shift of 1.5-2.5 days is a reasonable result if we consider westward traveling planetary waves from $16^{\circ} \mathrm{E}-21^{\circ} \mathrm{E}$ to the $95^{\circ} \mathrm{W}-114^{\circ} \mathrm{W}$ longitude sector, which is between two sites separated by $111^{\circ}-135^{\circ}$ in longitude. A 5 -day (with period varying between 4.5 and 6 days) planetary wave of zonal wave number 1 propagates westward by $60^{\circ}-80^{\circ}$ degrees of longitude per day, thus it propagates $111^{\circ}-135^{\circ}$ westward in 1.4-2.25 days. Figure 4 also demonstrates good coincidence in phase for waves over Canada, at Resolute Bay $\left(95^{\circ} \mathrm{W}\right)$ and at Yellowknife $\left(114^{\circ} \mathrm{W}\right)$, which are located quite close to each other in longitude, for days 217-230, 2004 (upper panel) and days 233-247, 2005 (lower panel).

Thus, the evidence is good that the meteor radars really do see the temperature perturbations caused by 5 -day, westward traveling, planetary waves and that the temperature perturbations are substantial (up to $15 \mathrm{~K}$ ), particularly over Yellowknife at $62^{\circ} \mathrm{N}$. We note that latitudes near $60^{\circ}$ are the most favorable of all our meteor-radar latitudes for groundbase NLC observations and 5-day periodicities have also been reported in NLC observed from the ground (Kirkwood et al., 2003).
3.3 Comparison of planetary waves between Odin stratospheric/mesospheric data and ground-based radar measurements near the mesopause

In the upper stratosphere, where ozone concentration is photochemically controlled, i.e., ozone is very short lived and is approximately in photochemical equilibrium (Brasseur and Solomon, 1986), an increase in temperature will increase the rate at which ozone is destroyed and therefore will tend to induce a change in ozone of the opposite sign. So temperature and ozone are anticorrelated. In the numerical simulation by Smith (1995) it was shown that the anticorrelation of mean ozone and temperature is due primarily to the temperature dependence of many of the photochemical reaction rates. The experimental work by Calisesi et al. (2004) has also demonstrated that the ozone is negatively correlated with temperature above $40 \mathrm{~km}$. Pendlebury et al. (2008) calculated time-lagged correlation of temperature and ozone in Northern hemisphere summer (at $52^{\circ} \mathrm{N}$ ) using the Canadian Middle Atmosphere Model (CMAM, a general circulation model of the troposphere-stratosphere-mesosphere system with fully interactive chemistry). They showed that, above approximately $35 \mathrm{~km}$, ozone anti-correlates with temperature, suggesting that it adjusts almost instantaneously to the temperature and an increase in temperature produces a simultaneous decrease in ozone due to an increase in ozone destruction. These results allow us to use ozone concentration above the middle stratosphere as a proxy for temperature 


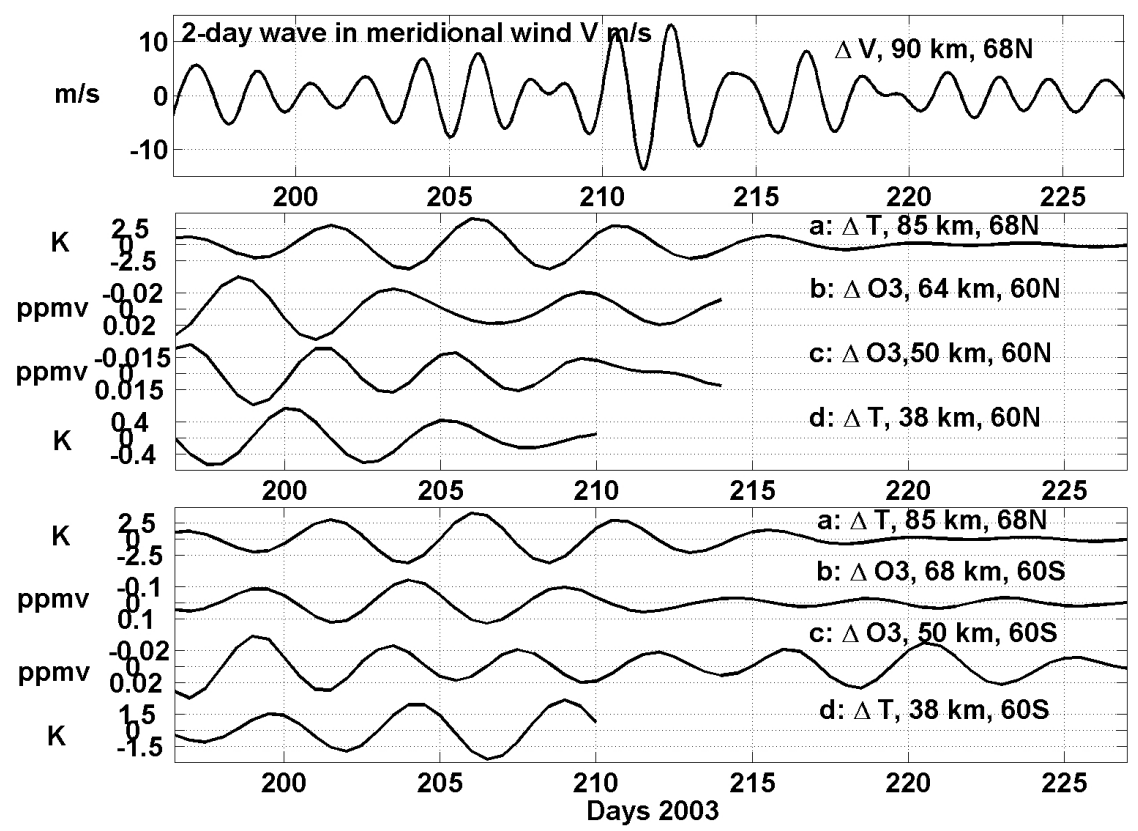

Fig. 5. Wave perturbations for 15 July-13 August 2003: Upper panel: 2-day wave from ground-based radar measurements of meridional wind $(\mathrm{m} / \mathrm{s})$ over Esrange $\left(67^{\circ} 56^{\prime} \mathrm{N}, 21^{\circ} 04^{\prime} \mathrm{E}\right)$, at $90 \mathrm{~km}$. Middle panel: 5-day perturbations: (a) from ground-based radar measurements of temperature over Esrange $\left(67^{\circ} 56^{\prime} \mathrm{N}, 21^{\circ} 04^{\prime} \mathrm{E}\right)$, at $85 \mathrm{~km}$. (b-d) from Odin retrievals at latitude $=60^{\circ} \mathrm{N}$, longitude $=21^{\circ} \mathrm{E}$ : for ozone (ppmv) at $64 \mathrm{~km} \mathrm{(b)} \mathrm{and} \mathrm{at} 50 \mathrm{~km}(\mathrm{c})$, for temperature (K) at $38 \mathrm{~km}(\mathrm{~d})$, (Note: reverse scale for ozone). Lower panel: 5-day perturbations: (a) same as on the middle panel. (b-d) from Odin retrievals at latitude $=60^{\circ} \mathrm{S}$, longitude $=21^{\circ} \mathrm{E}$ : for ozone (ppmv) at $68 \mathrm{~km} \mathrm{(b)} \mathrm{and} \mathrm{at} 50 \mathrm{~km}(\mathrm{c})$, for temperature $(\mathrm{K})$ at $38 \mathrm{~km}(\mathrm{~d})$, (Note: reverse scale for ozone).

in order to trace the 5-day planetary waves to higher altitude. We need to do this since good-quality temperature retrievals from Odin are not available to such high altitudes as reliable estimates of ozone concentration.

Our aim is to try to follow the wave perturbations from the stratosphere up through the mesosphere to the mesopause, to see if their behaviour is inconsistent with any or all of the three possible sources we consider for 5-day waves at the summer mesopause. The first possible source is vertical wave propagation from lower to upper altitudes in the summer hemisphere. The second possibility is the same process but in the winter hemisphere, with subsequent horizontal travel of the wave at mesospheric heights into the opposite, summer, hemisphere. We use changes in amplitude of the waves detected in the Odin data at different heights and in different hemispheres as a diagnostic of the first two possible sources. The third possible source is baroclinic instability of the easterly jet in the in the summer mesosphere. Since this instability is expected to be most effective in generating 2day waves (see introduction), we use the amplitude of 2-day waves as a diagnostic of the third source.

In Figs. 5-8 the 2-day wind perturbations (upper panel) and 5-day temperature perturbations (middle and lower panels), close to the summer mesopause at $68^{\circ}-69^{\circ} \mathrm{N}$, are plotted together with the perturbations at lower altitudes (38$68 \mathrm{~km}$ ) in both hemispheres at $60^{\circ} \mathrm{N}$ (middle panel) and $60^{\circ} \mathrm{S}$ (lower panel). The curves (a) in the middle and lower panels represent 5-day temperature perturbations (obtained from the meteor radar data). Other curves are calculated from the Odin data: lines (b) and (c) show the 5-day ozone perturbations at $64-68 \mathrm{~km}$ and $48-50 \mathrm{~km}$, respectively; line (d) shows the 5-day temperature perturbation at $38-46 \mathrm{~km}$. Note that a reverse scale is applied for ozone, on plots (b) and (c), because we use ozone as a proxy for temperature in the upper stratosphere and higher up, where an anticorrelation should be observed between temperature and ozone. The perturbation amplitudes and phases have been discussed earlier in Sect. 3.1.2, so now we pay the most attention to the wave envelope, i.e. to the amplitude changes over time at the different heights. Each year is discussed separately in the following paragraphs.

Figure 5 shows the 5-day perturbations for the summer of 2003. One can see a similar wave envelop for days 197-210 in both hemispheres at $38-68 \mathrm{~km}$ (middle and lower panels). At the summer polar mesopause (a), the amplitude is highest between days 200-213 and at the beginning of this interval (days 200-207) the perturbation amplitude is also high at lower altitudes $(38-68 \mathrm{~km})$ in the same hemisphere at $60^{\circ} \mathrm{N}$ and in the opposite hemisphere at $60^{\circ} \mathrm{S}$. As the highest amplitude is observed almost simultaneously in the both $\mathrm{NH}$ and $\mathrm{SH}$, the origin of the wave around the summer mesopause could be located in either hemisphere at lower heights. In spite of the wave attenuation that is observed below the mesopause in both hemispheres for days 208-213, 


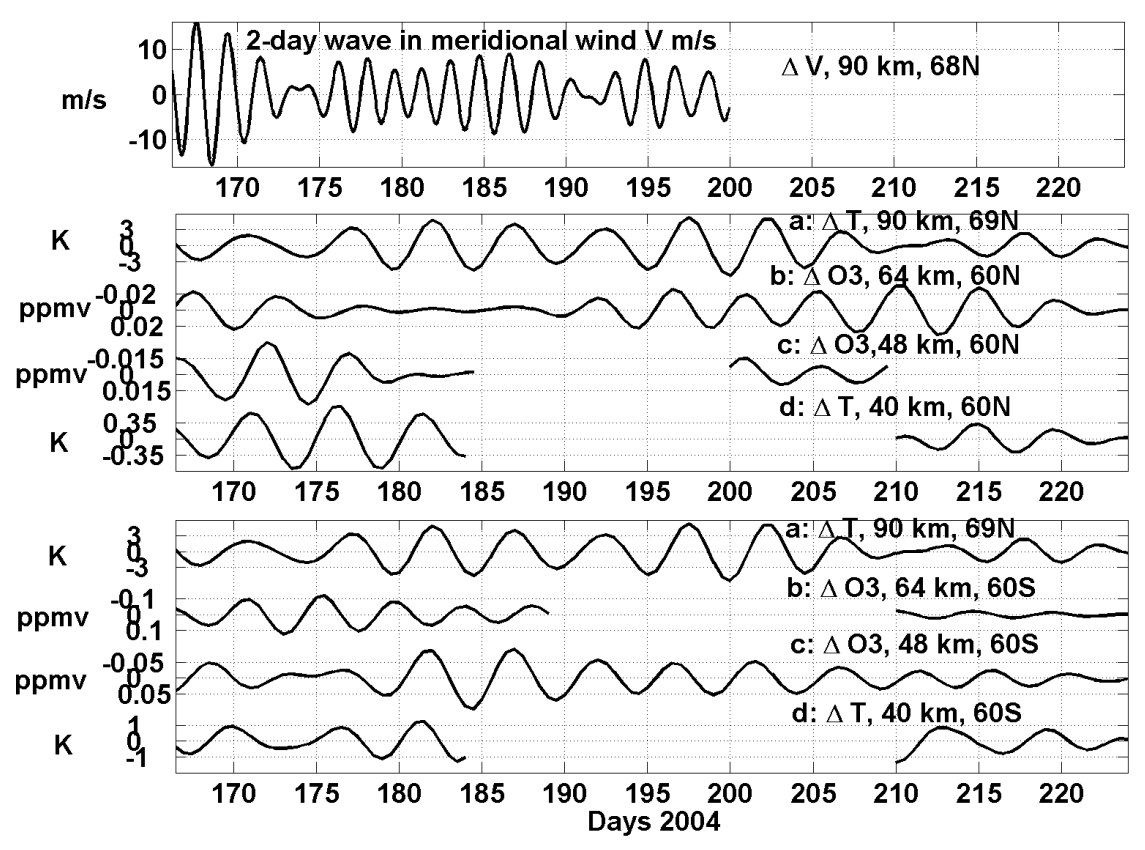

Fig. 6. Wave perturbations for 14 June-11 August 2004: Upper panel: 2-day wave from ground-based radar measurements of meridional wind $(\mathrm{m} / \mathrm{s})$ over Esrange $\left(67^{\circ} 56^{\prime} \mathrm{N}, 21^{\circ} 04^{\prime} \mathrm{E}\right)$, at $90 \mathrm{~km}$. Middle panel: 5-day perturbations: (a) from ground-based radar measurements of temperature over Andenes $\left(69^{\circ} 17^{\prime} \mathrm{N}, 16^{\circ} 00^{\prime} \mathrm{E}\right)$, at $90 \mathrm{~km}$. (b-d) from Odin retrievals at latitude $=60^{\circ} \mathrm{N}$, longitude $=21^{\circ} \mathrm{E}$ : for ozone (ppmv) at $64 \mathrm{~km}$ (b) and at $48 \mathrm{~km}$ (c), for temperature (K) at $40 \mathrm{~km}(\mathrm{~d})$, (Note: reverse scale for ozone). Lower panel: 5-day perturbations: (a) same as on the middle panel. $(\mathrm{b}-\mathrm{d})$ same as on the middle panel but for latitude $=60^{\circ} \mathrm{S}$. (Note: reverse scale for ozone).

the perturbation amplitude around the summer mesopause remains large. This could in principle be a result of a change in wave amplification as it propagates upward, due to changes in background winds. However, considering the amplitude in the 2-day wave (upper panel), we see that it has maxima around days 206 and 212. These occur in about the same interval as the maximum amplitude of the 5-day wave at $85 \mathrm{~km}$, so it is possible that they are both influenced simultaneously by the baroclinic instability.

A similar comparison of the wave pattern in both hemispheres for the summer of 2004 is shown in Fig. 6. Curve (a) demonstrates that the 5-day perturbation amplitude at the summer polar mesopause is rather high for days 175-205. In the $\mathrm{NH}$ (middle panel) the perturbation amplitude at 40$48 \mathrm{~km}(\mathrm{~d}, \mathrm{c})$ is high during days $170-185$ but it is attenuated at $64 \mathrm{~km}$ (b). Note that this interval covers midsummer (day 175), when the stratospheric easterlies are strongest, and direct upward propagation through those easterlies should be most difficult. Starting at day 195 the perturbation amplitude at $64 \mathrm{~km}$ in the $\mathrm{NH}$ grows and could be the source of the increase in wave amplitude seen at $90 \mathrm{~km}$, lasting until day 208 (middle panel, curve (a)). In the opposite, winter, hemisphere at $60^{\circ} \mathrm{S}$ (lower panel), the perturbation amplitude is high for days 175-188 and increases between 48 and $64 \mathrm{~km}$. So the wave seems to propagate upwards in the SH and could in principle propagate to the summer hemisphere at mesospheric heights. However, the 2-day wave (upper panel) shows 2 bursts of higher amplitude which correlate well with the 5-day wave at $90 \mathrm{~km}$, days 175-190 and 194200 , so the baroclinic instability seems a good candidate for both waves in this case (which is very close to solstice).

Figure 7 shows the 5-day perturbations for the summer of 2005. The highest amplitudes around the summer mesopause (curve a) at $85 \mathrm{~km}$ are seen for days 225-240. At the same time, the waves in the $\mathrm{NH}$ (middle panel) at lower levels do not show any increase in amplitude before day 240. However wave amplitude at $64 \mathrm{~km}$ is as high as that at $50 \mathrm{~km}$ so it is possible that the wave propagates vertically in the polar summer hemisphere between 64 and $85 \mathrm{~km}$, and that the increased amplitude at $85 \mathrm{~km}$ is due to changes in background wind. There is no information about planetary waves in the SH (lower panel) above $42 \mathrm{~km}$ for these days but there is a noticeable amplitude increase at $60^{\circ} \mathrm{S}$ at $42 \mathrm{~km}$ at about the same time. So we cannot rule out the possibility that the wave packet at the $\mathrm{NH}$ mesopause has its source in the $\mathrm{SH}$. The timing of the wave packet, days 225-240, is long after solstice and coincides with a reduction in the amplitude of the 2-day wave (upper panel) - so it seems unlikely that the baroclinic instability can be the source in this case. Further, it should be noted that the high wave amplitudes in the $\mathrm{NH}$ at 50 and $64 \mathrm{~km}$ from day $240 \mathrm{on}$, correspond to the period close to autumnal equinox when stratospheric winds have generally turned to westerly, favoring upward propagation. On the other hand, no amplitude growth is observed at $85 \mathrm{~km}$ for this 


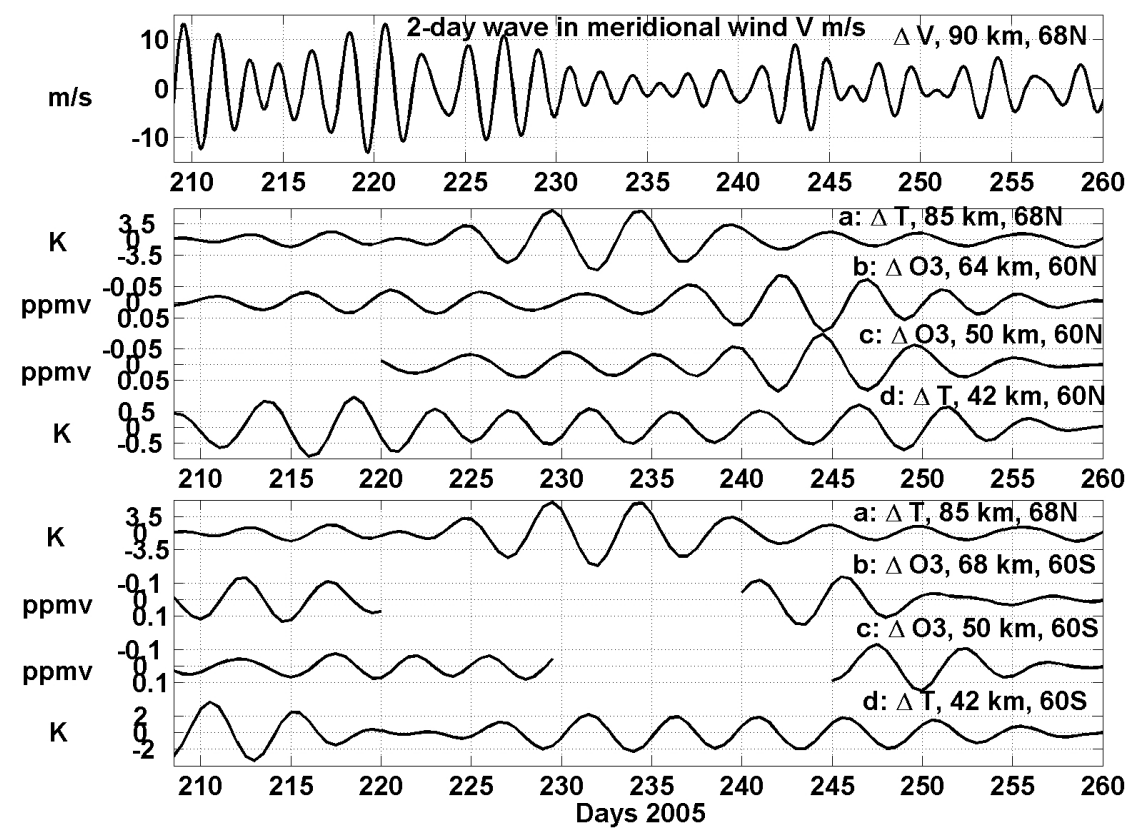

Fig. 7. Wave perturbations for 27 July-17 September 2005: Upper panel: 2-day wave from ground-based radar measurements of meridional wind $(\mathrm{m} / \mathrm{s})$ over Esrange $\left(67^{\circ} 56^{\prime} \mathrm{N}, 21^{\circ} 04^{\prime} \mathrm{E}\right)$, at $90 \mathrm{~km}$. Middle panel: 5-day perturbations: (a) from ground-based radar measurements of temperature over Esrange $\left(67^{\circ} 56^{\prime} \mathrm{N}, 21^{\circ} 04^{\prime} \mathrm{E}\right)$, at $85 \mathrm{~km}$. (b-d) from Odin retrievals at latitude $=60^{\circ} \mathrm{N}$, longitude $=21^{\circ} \mathrm{E}$ : for ozone $(\mathrm{ppmv})$ at $64 \mathrm{~km} \mathrm{(b)} \mathrm{and} \mathrm{at} 50 \mathrm{~km}(\mathrm{c})$, for temperature $(\mathrm{K})$ at $42 \mathrm{~km}(\mathrm{~d})$, (Note: reverse scale for ozone). Lower panel: (a) same as on the middle panel. (b-d) from Odin retrievals at latitude $=60^{\circ} \mathrm{S}$, longitude $=21^{\circ} \mathrm{E}$ : for ozone (ppmv) at $68 \mathrm{~km}(\mathrm{~b})$ and at $50 \mathrm{~km}(\mathrm{c})$, for temperature $(\mathrm{K})$ at $42 \mathrm{~km}$ (d), (Note: reverse scale for ozone).

time interval indicating no direct connection with perturbations from lower heights.

Figure 8 shows the 5-day perturbations for the period 22 May-17 June 2007. Around the summer mesopause, curve (a), the highest amplitudes are observed for days 150162.

At the lower heights at $60^{\circ} \mathrm{N}$ (middle panel) the perturbations show close phase consistency and increasing amplitude with height, consistent with vertical propagation during days 150-155 between 46 and $85 \mathrm{~km}$. In the SH (lower panel) the perturbations are extremely small at 48 compared to $64 \mathrm{~km}$, so the data is hard to interpret. The 2-day wave (upper panel) shows a clear amplitude maximum at the same time as the maximum in the 5-day wave, so that baroclinic instability seems also to be a possible source in this case.

In summary, 5-day wave energy at mesopause heights is generally seen in short "packets" of a few cycles of higher amplitude. Amplitude changes are sometimes correlated at all heights between 40 and $85 \mathrm{~km}$ but more often it is hard to see clear correlation over all heights. When we test whether Northern-Hemisphere or Southern-Hemisphere planetary waves at lower altitudes are a possible source of the fluctuations at the summer mesopause we find that both are possible in all except one case (close to solstice when we find evidence against a NH source). Correlation between bursts in 5-day and in 2-day waves at mesopause heights is rather good in two cases, supporting the possibility that both are caused by baroclinic instability. However in one case of a 5-day wave, 50-65 days after solstice, the baroclinic instability seems an unlikely source.

\section{Conclusions}

In this paper we have used global observations from the Odin satellite data and ground-based meteor-radar observations from Scandinavia and Canada to investigate the propagation of 5-day waves from the stratosphere to the mesopause in the Northern Hemisphere summers of 2003, 2004, 2005 and 2007.

The satellite data show 5-day planetary waves in temperature up to $54 \mathrm{~km}$ height. These waves have the expected higher amplitudes in the winter hemisphere and (usually) inter-hemispheric symmetry in phase. Wave amplitudes are about $2 \mathrm{~K}$ (maximum $\sim 4 \mathrm{~K}$ ) in the winter stratosphere and about $0.5 \mathrm{~K}$ (maximum $\sim 1 \mathrm{~K}$ ) in the summer stratosphere.

The Odin data show 5-day waves in ozone concentration at $24-68 \mathrm{~km}$ height. In general the wave amplitude in ozone is about $0.0025-0.05 \mathrm{ppmv}$ in the summer hemisphere and about $0.05-0.1 \mathrm{ppmv}$ in winter. There is one case when almost equal amplitudes in the ozone wave $(\sim 0.1 \mathrm{ppmv})$ were observed in both hemispheres: during the $\mathrm{NH}$ autumnal equinox of 2005 when the 5-day waves have approximately the same magnitudes relative to the equator. 


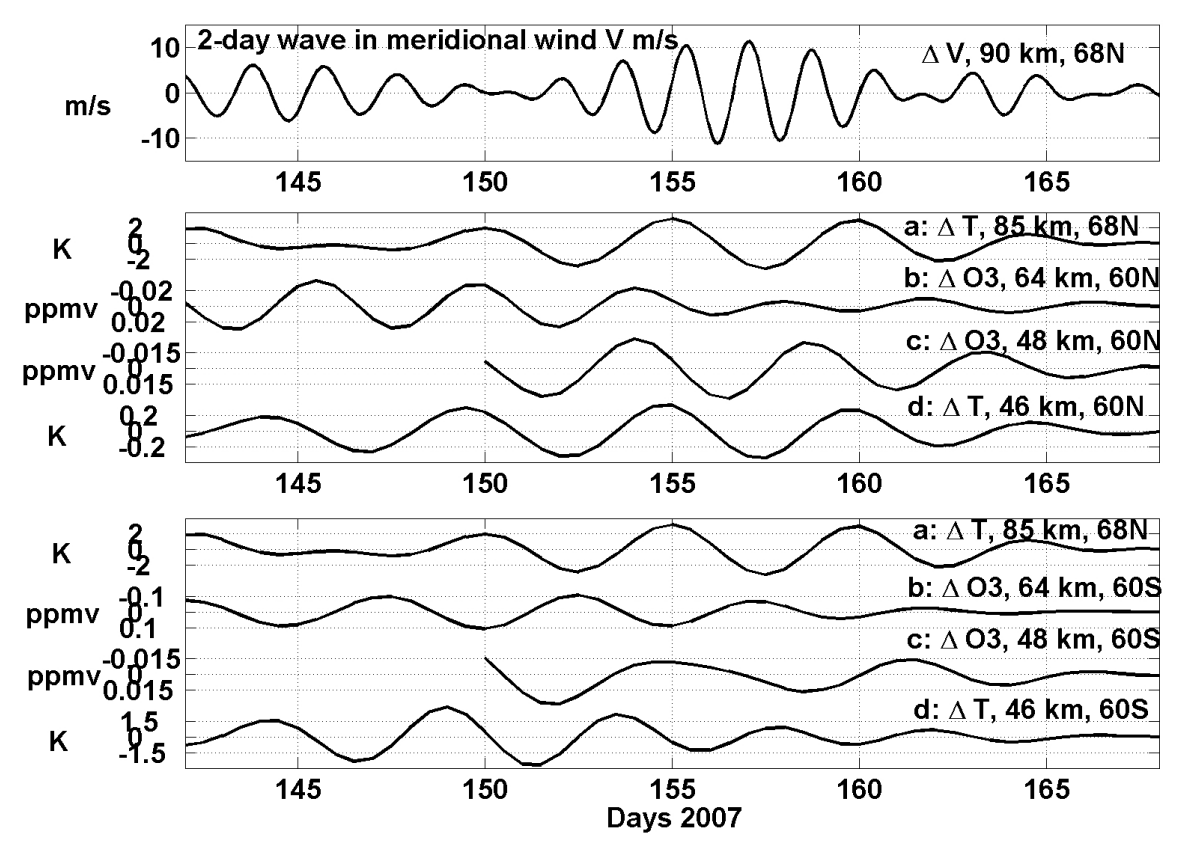

Fig. 8. Wave perturbations for 22 May-17 June 2007: Upper panel: 2-day wave from ground-based radar measurements of meridional wind $(\mathrm{m} / \mathrm{s})$ over Esrange $\left(67^{\circ} 56^{\prime} \mathrm{N}, 21^{\circ} 04^{\prime} \mathrm{E}\right)$, at $90 \mathrm{~km}$. Middle panel: 5-day perturbations:: a) from ground-based radar measurements of temperature over Esrange $\left(67^{\circ} 56^{\prime} \mathrm{N}, 21^{\circ} 04^{\prime} \mathrm{E}\right)$, at $85 \mathrm{~km}$. (b-d) from Odin retrievals at latitude $=60^{\circ} \mathrm{N}$, longitude $=21^{\circ} \mathrm{E}$ : for ozone $(\mathrm{ppmv})$ at $64 \mathrm{~km} \mathrm{(b)} \mathrm{and} \mathrm{at} 48 \mathrm{~km}(\mathrm{c})$, for temperature $(\mathrm{K})$ at $46 \mathrm{~km}(\mathrm{~d})$, (Note: reverse scale for ozone). Lower panel: (a) same as on the middle panel. $(\mathrm{b}-\mathrm{d})$ same as on the middle panel but for latitude $=60^{\circ} \mathrm{S}$. (Note: reverse scale for ozone).

Study of the phase change in the ozone perturbations with height in the summer hemisphere at $60^{\circ} \mathrm{N}$ shows phase shifts up to $180^{\circ}$ between $48-50$ and $64 \mathrm{~km}$, which can in principle be explained by different background wind conditions.

The 5-day temperature perturbations at the summer mesopause, derived from the meteor-radar observations at $85-90 \mathrm{~km}$ height show high amplitudes (up to $15 \mathrm{~K}$ ) and 1-2.5 day phase shifts between Scandinavia and Canada, consistent with the expected westward propagation of 5-day planetary waves.

Wave amplitudes are highly variable in time, with "packets" of high amplitude lasting only few cycles. Comparison between wave envelopes in both winter and summer stratosphere/lower mesosphere and at the summer mesopause shows no evidence that wave propagation to the summer mesopause is inhibited in the summer hemisphere, except in one case, close to equinox. For some periods, simultaneous amplitude changes are seen at all heights in both hemispheres, so that the possibility that waves reach the summer mesopause by upward propagation through the winter stratosphere and mesosphere cannot be ruled out. For other periods, no good correlation is seen between amplitude changes at the mesopause and at lower heights, suggesting sensitivity to other factors. One such factor could be background atmospheric winds (as in the numerical simulation results of Geisler and Dickinson, 1976). Another possible influence is in-situ generation or amplification of the 5-day wave in the summer mesosphere as result of the baroclinic instability (Plumb, 1983; Garcia et al., 2005; Riggin et al., 2006). However this is unlikely to be effective late in the summer when high-amplitude 5-day waves can still be seen.

Acknowledgements. We thank the anonymous reviewers for their constructive comments on the original manuscript. This work was financed by the Swedish National Space Board.

Topical Editor U.-P. Hoppe thanks two anonymous referees for their help in evaluating this paper.

\section{References}

Andrews, D. G., Holton, J. R., and Leovy, C. B.: Middle Atmosphere Dynamics, Academic Press, London, 169-171, 1987.

Brasseur, G. and Solomon, S.: Aeronomy of the middle atmosphere, D. Reidel, Norwell, 204-211, 1986.

Calisesi, Y., Kämpfer, N., Ruffieux, D., and Viatte, P.: Upper stratospheric ozone anomalies at the winter midlatitudes, Proceedings of the XX Quadrennial Ozone Symposium, edited by: Zerefos, Ch., vol. I, 308-311, 2004.

Garcia, R. R., Lieberman, R., Russell III, J. M., and Mlynczak, M. G.: Large-scale waves in the mesosphere and lower thermosphere observed by SABER, J. Atmos. Sci., 62, 4384-4399, 2005.

Geisler, J. E. and Dickinson, R. E.: The five-day wave on a sphere with realistic zonal winds, J. Atmos. Sci., 33, 632-641, 1976.

Frisk, U., Hagström, M., Ala-Laurinaho, J., Andersson, S., Berges, J.-C., Chabaud, J.-P., Dahlgren, M., Emrich, A., Florén, H.-G., 
Florin, G., Fredrixon, M., Gaier, T., Haas, R., Hirvonen, T., Hjalmarsson, Å., Jakobsson, B., Jukkala, P., Kildal, P., Kollberg, E., Lassing, J., Lecacheux, A., Lehikoinen, P., Lehto, A., Mallat, J., Marty, C., Michet, D., Narbonne, J., Nexon, M., Olberg, M., Olofsson, O., Olofsson, G., Origné, A., Petersson, M., Piironen, P., Pons, R., Pouliquen, D., Ristocelli, I., Rosolen, C., Rouaix, G., Räisänen, A., Serra, G., Sjöberg, F., Stenmark, L., Torchinsky, S., Tuovinen, J., Ullberg, C., Vinterhav, E., Wadefalk, N., Zirath, H., Zimmermann, P., and Zimmermann, R.: The Odin satellite: I. Radiometer design and test, Astron. Astrophys., 402(3), L27-34, 2003.

Hirooka, T.: Normal mode Rossby waves as revealed by UARS/ISAMS Observations, J. Atmos. Sci., 57, 1277-1285, 2000.

Hirota, I. and Hirooka, T.: Normal mode Rossby wave observed in the upper stratosphere. Part I: first symmetric modes of zonal wavenumbers 1 and 2, J. Atmos. Sci., 41, 1253-1267, 1984.

Hirota, I. and Hirooka, T.: Normal mode Rossby wave observed in the upper stratosphere. Part II: second asymmetric and symmetric modes of zonal wavenumbers 1 and 2, J. Atmos. Sci., 42, 536548, 1985.

Hocking, W. K., Singer, W., Bremer, J., Mitchell, N. J., Batista, P., Clemesha, B., and Donner, M.: Meteor Radar Temperatures at multiple sites derived with SKiYMET radars and compared to $\mathrm{OH}$, rocket and lidar measurements, J. Atmos. Solar-Terr. Phys., 66, 585-593, 2004.

Holton, J. R.: The role of gravity wave induced drag and diffusion in the momentum budget of the mesosphere, J. Atmos. Sci., 39, 791-799, 1982.

Kirkwood, S. and Rechou, A.: Planetary-wave modulation of PMSE, Geophys. Res. Lett., 25, 4509-4512, 1998.

Kirkwood, S., Barabash, V., Brändström, U., Moström, A., Stebel, K., Mitchell, N., and Hocking, W.: Noctilucent clouds, PMSE and 5-day planetary waves: a case study, Geophys. Res. Lett., 29, 1411-1414, 2002.

Kirkwood, S. and Stebel, K.: Influence of planetary waves on noctilucent cloud occurrence over NW Europe, J. Geophys. Res., 108(D8), 8440-8455, 2003.

Kopp, G., Belova, A., Diez y Riega, V. E., Groß, J., Hochschild, G., Hoffmann, P., Murtagh, D., Raffalski, U., and Urban J.: Intercomparison of Odin-SMR ozone profiles with ground-based millimetre-wave observations in the Arctic, the mid-latitudes, and the tropics, Can. J. Phys. 85, 1097-1110, 2007.

Lawrence, A. R. and Jarvis, M. J.: Simultaneous observations of planetary waves from 30 to $220 \mathrm{~km}$, J. Atmos. Solar-Terr. Phys., 65, 765-777, 2003.

Matsuno, T.: A quasi-one-dimensional model of the middle atmosphere circulation interacting with internal gravity waves, J. Meteorol. Soc. Japan, 60, 215-226, 1982.

Merkel, A. W., Thomas, G. E., Palo, S. E., and Bailey, S. M.: Observations of the 5-day planetary wave in PMC measurements from the Student Nitric Oxide Explore Satellite, Geophys. Res. Lett., 30(4), 1196, doi:10.1029/2002GL016524, 2003.

Merkel, A. W., Garcia, R. R., Bailey, S. M., and Russell III, J. M.: Observational studies of planetary waves in PMCs and mesospheric temperature measured by SNOE and SABER, J. Geophys. Res., 113, D14202, doi:10.1029/2007JD009396, 2008.

Miyoshi, Y.: Numerical simulation of 5-day and 16-day waves in the mesopause region, Earth Planets Space, 51, 763-772, 1999.
Murtagh, D., Frisk, U., Merino, F., Ridal, M., Jonsson, A., Stegman, J., Witt, G., Eriksson, P., Jimenez, C., Mégie, G., de La Noëë, J., Ricaud, P., Baron, P., Pardo, J.-R., Hauchecorne, A., Llewellyn, E. J., Degenstein, D. A., Gattinger, R. L., Lloyd, N. D., Evans, W. F. J., McDade, I. C., Haley, C. Sioris, C., von Savigny, C., Solheim, B. H., McConnell, J. C., Strong, K., Richardson, E. H., Leppelmeier, G. W., Kyrölä, E., Auvinen, H., and Oikarinen, L.: An overview of the Odin atmospheric mission, Can. J. Phys., 80, 309-319, 2002.

Olberg, M., Frisk, U., Lecacheux, A., Olofsson, O., Baron, P. Bergmann, P., Florin, G., Hjalmarsson, ̊., Larsson, B., Murtagh, D., Olofsson, G., Pagani, L., Sandquist, A., Teyssier, D., Torchinsky, S., and Volk, K.: The Odin satellite: II. Radiometer data processing and calibration, Astron. Astrophys., 402(3), L35-38, 2003.

Pancheva, D., Mitchell, N. J., Manson, A. H., Meek, C. E., Jacobi, Ch., Portnyagin, Yu., Merzlyakov, E., Hocking, W. K., MacDougall, J., Singer, W., Igarashi, K., Clark, R. R., Riggin, D. M., Franke, S. J., Kürschner, D., Fahrutdinova, A. N., Stepanov, A. M., Kashcheyev, B. L., Oleynikov A. N., and Muller, H. G.: Variability of the quasi-2-day wave observed in the MLT region during the PSMOS campaign of June-August 1999, J. Atmos. Solar Terr. Phys., 66, 539-565, 2004.

Pendlebury, D., Shepherd, T. G., Pritchard, M., and McLandress, C.: Normal mode Rossby waves and their effects on chemical composition in the late summer stratosphere, Atmos. Chem. Phys., 8, 1925-1935, 2008, http://www.atmos-chem-phys.net/8/1925/2008/.

Plumb, R. A.: Baroclinic instability of the summer mesosphere: a mechanism for the quasi-two-day wave?, J. Atmos. Sci., 40, 262-270, 1983.

Prata, A. J.: Observations of the 5-Day Wave in the Stratosphere and Mesosphere, J. Atmos. Sci., 46, 2473-2477, 1989.

Prata, A. J.: Travelling waves in Nimbus-7 SBUV ozone measurements: Observations and theory, Q. J. Roy. Meteorol. Soc., 116, 1091-1122, 1990.

Riggin, D. M., Liu, H.-L., Lieberman, R. S., Roble, R. G., Russell III, J. M., Mertens, C. J., Mlynczak, M. G., Pancheva, D., Franke, S. J., Murayama, Y., Manson, A. H., Meek, C. E., and Vincent, R. A.: Observations of the 5-day wave in the mesosphere and lower thermosphere, J. Atmos. Solar-Terr. Phys., 68, 323-339, 2006.

Rosenlof, K. H. and Thomas, R. J.: Five-day mesospheric waves observed in solar mesosphere explorer ozone, J. Geophys. Res., 95, 895-899, 1990.

Salby, M. L.: Rossby normal modes in nonuniform background configurations. Part I: Simple fields, J. Atmos. Sci., 38, 18031826, 1981a.

Salby, M.L.: Rossby normal modes in nonuniform background configurations. Part II: equinox and solstice conditions, J. Atmos. Sci., 38, 1827-1840, 1981b.

von Savigny, C., Robert, C., Bovensmann, H., Burrows, J. P., and Schwartz, M.: Satellite observations of the quasi 5-day wave in noctilucent clouds and mesopause temperature, Geophys. Res. Lett., 34, L24808, doi:10.1029/2007GL030987, 2007.

Schwartz, M. J., Lambert, A., Read, G. L. M. W. G., Livesey, N. J., Froidevaux, L., Ao, C. O., Bernath, P. F., Boone, C. D., Cofield, R. E., Daffer, W. H., Drouin, J. B., Fetzer, E. J., Fuller, R. A.,Jarnot, R. F., Jiang, J. H., Knosp, B. W., Krüger, K., Li, 
J.-L. F., Mlybcak, M. G., Pawson III, S., Russell, J. M. R., Santee, M. L., Snyder, W. V., Stek, P. C., Thurstans, R. P., Tompkins, A. M., Wagner, P. A., Walker, K. A., Waters, J. W., and Wu, D. L.: Validation of the Aura Microwave Limb Sounder temperature and geopotential height measurements, J. Geophys. Res., 113, D15S11, doi:10.1029/2007JD008783, 2008.

Smith, A. K.: Numerical simulation of global variations of temperature, ozone, and trace species in the stratosphere, J. Geophys. Res., 100(D1), 1253-1270, 1995.
Urban, J., Lautié, N., Le Flochmoën, E., Jiménez, C., Eriksson, P., de La Noë, J., Dupuy, E., Ekström, M., El Amraoui, L., Frisk, U., Murtagh, D., Olberg, M., and Ricaud, P.: Odin/SMR limb observations of stratospheric trace gases: Level 2 processing of ClO, N2O, HNO3, and O3, J. Geophys. Res., 110, D14307, doi:10.1029/2004JD005741, 2005.

Venne, D.: The horizontal structure of traveling planetary-scale waves in the upper stratosphere, J. Geophys. Res., 90, 38693879, 1985. 